\title{
Maternalism, Co-responsibility, and Social Equity: A Typology of Work-Family Policies
}

\section{Merike Blofield ${ }^{1}$ and Juliana Martínez Franzoni2 ${ }^{2 *}$}

This paper provides a conceptual lens to address the complexity of policies involved in reconciling paid work and family responsibilities. Our typology classifies policies by how they intervene in the relation between paid work and family relations-by alternating paid and unpaid work, by transferring unpaid work outside the family or by formalizing home-based paid care-and by disaggregating implications for both social equity and gender relations (maternalism versus paternal or state co-responsibility) across policies. The paper makes a three-fold contribution. First, our typology looks at a set of policies rather than specific policies or overall policy regimes. Second, it helps disaggregate implications for gender and social equity. Third, it allows for comparative analysis of small and large numbers of cases across policy stages. Although we draw on Latin America, ${ }^{1}$ our typology has broader application and is especially suited to examining countries with high-income inequality.

\section{Introduction}

The increase in women's labor force participation rates and changing family composition has drawn scholarly attention to policies-or lack thereof-at the intersection of families and labor markets or, between paid and unpaid work. How do these policies reshape relations between women and men? Does state intervention reinforce the notion that unpaid work is women's sole responsibility or suggest that men and/or the state should also be involved? In the past two decades, a wealth of literature has addressed this matter, comparing specific labor and social policies such as flexible work time, paternity leave, and childcare across countries and classifying countries in terms of policy regimes. Both lines of inquiry have made a valuable contribution to understanding how policies reshape women's lives and gender relations but focus mostly on advanced industrialized countries, where labor markets

\footnotetext{
${ }^{1}$ University of Miami.

${ }^{2}$ University of Costa Rica.

*juliana.martinez@ucr.ac.cr 
are largely formal and where income distribution is more equal than in Latin America or most of the developing world. ${ }^{2}$

This paper contributes to the conceptualization of work-family reconciliation policies by developing a typology based on policy types and their implications rather than on broader regimes. We focus on policies that have direct effects (intentionally or not) on the relation between paid work and familybased unpaid care. ${ }^{3}$ We are interested in the ways these policies affect this relation: Do they sequence paid and unpaid work? Do they remove some of the unpaid work from the sphere of the family? Do they regulate occupations devoted to paid care? What are their socio-economic and gender implications? Do they promote more equal relations across classes and between women and men or do they reinforce women's role as caregivers or exacerbate polarization across socioeconomic strata? Focusing on policies toward families with small children, where the tensions between work and family are often the greatest, ${ }^{4}$ we classify policies according to how they intervene in the reconciliation between work and family and examine their implications for gender and socioeconomic via four concepts: whether they promote maternalism, paternal co-responsibility, state co-responsibility, and/or social equity.

We draw on Latin America which, in comparison with advanced industrialized countries, has less developed welfare states with more modest reach. States in Latin America also redistribute much less than advanced industrialized countries. Historically and with remarkable exceptions, only primary education reached everybody on the basis of citizenship. The bulk of social transfers is provided by contributory systems and therefore restricted to workers in the formal sector who tend to be better off. Some of these contributory systems were privatized during the 1990s, becoming even more regressive. $^{5}$

More recently public policies in Latin American countries have begun to pay increasing attention to extreme poverty through non-contributory, conditional cash transfer programs targeted to the very poor. These programs have had positive results on levels of absolute poverty, health checkups, and school attendance. We also see extensions of what scholars refer to as "basic universalism"- a minimum set of transfers or (primarily healthcare) services (Filgueira 1998; Molina 2006; Pribble 2013) to all. Policies on gender, the labor force, and family in the region have until recently been premised on the assumption that caregiving is a private matter with the implicit expectation of a traditional family with a breadwinner father, a stay-at-home mother, perhaps a grandmother or unmarried aunt and, certainly in the case of legislators responsible for contemplating these issues, a nanny, with no need for a state role in care provision. In few countries are such assumptions in accordance with social reality for a majority of the population (if they ever were). Parallel to the combination of rapid changes in the organization of families and labor markets, on the one hand, and relative inertia in class and gender relations, on the other, interactions between families and labor markets have come under increasing 
stress, and during the past decade governments have begun to respond to changing social realities.

How to understand these changes? While Latin America forms the basis for the development of the typology we present below, the question we ask and the typology we propose to address the matter, are not region-specific but can be used for other parts of the world, especially to examine countries where informal labor markets and high income inequalities require that class be brought into the picture to make sense of transformations in gender relations. Below we outline the key features of labor markets and diversified family structures in Latin America. We then discuss the literature on the reconciliation of work and family. The core of the paper is presented in sections Conceptualization and Putting our Categories to Use, where we elaborate our typology and categorize policies on whether and how they promote gender and social equity.

\section{Paid and Unpaid Work in Latin America: Changing Social Structures, Incipient Policies}

Assessing work-family reconciliation policy in Latin American countries calls for analytic tools that disentangle socioeconomic from gender inequality. On the one hand, as in the rest of the western world, the socioeconomic position of women in Latin America has been rapidly changing (Chioda 2011). The economic crisis of the 1980s constituted a turning point in women's living conditions as they began joining the labor force en masse. What was initially a transitory response by families struggling to make ends meet became an irreversible trend. In 1990, thirty-two out of every one hundred women had a paid job and by 2010 it had increased to fifty-three out of every one hundred women. Among women of childbearing age, the figure reaches 70 percent. Family composition reflects these changes: there are currently more dual-earner than male-breadwinner families, and female-headed families have increased from 23 percent of households two decades ago to 30 percent of households today (UNDP/ILO 2009).

Women's educational levels have also increased, now surpassing men's. And, within a few decades, the region has undergone demographic changes that in Europe and North America took over one hundred years, as fertility rates have declined to close to, or even below, replacement level (ECLAC 2009, 2010) while life expectancy has increased. Still, women earn only 70 percent of men's earnings despite higher levels of education (UNDP/ILO 2009). There are various reasons for these gaps in Latin America, just as there are in advanced industrialized countries, but one important one in both regions is the unequal division of family responsibilities. Time-use surveys indicate that care work and housework continue to be carried out mostly by the women in the family, producing the so-called "double burden" (ECLAC 2010; UNDP/ ILO 2009). Such care responsibilities pose barriers to joining full-time working 
arrangements, force work interruptions for child-rearing, and push women to the informal sector (see Blofield and Madalozzo 2013; Filgueira et al. 2011; Martínez Franzoni 2008; Martínez Franzoni and Voorend 2009, 2011).

Changes in women's position have taken place against the backdrop of deep-seated socioeconomic inequalities. Despite improvements over the past decade, Latin America remains the most unequal region in the world (Cornia 2010; ECLAC 2011; López-Calva and Lustig 2010), which means that tensions at the intersection of paid work and family responsibilities are dealt with in highly stratified ways. They are also embedded in highly informal labor relations, meaning that much paid work, whether salaried or non-salaried, is unregulated and lacks social protection (ILO 2012). ${ }^{6}$

Class and gender inequalities interact in a variety of ways. First, labor force participation rates among women from lower-income quintiles remain on average 30 percent below that of women from higher-income quintiles, often due to their difficulties in resolving their care responsibilities (ECLAC 2009). The likelihood of poor families overcoming poverty is closely intertwined with the presence of at least two income earners (UNDP/ILO 2009). Thus, women's inability to participate in the labor market reduces the income of already lowincome households, aggravating poverty and social inequality (ECLAC 2009). Second, not only do women have less labor protection on average than menregionally, only 36 percent of women in urban areas have social security versus 49 percent of men (UNDP/ILO 2009) — but poor women have substantially less labor protection than wealthier women. This is because they tend to be selfemployed or in unprotected occupations like paid domestic work, threequarters of whom still lacked pensions as of 2008 (ILO 2011). In addition, lowerincome women have more children: the total fertility rate of women with less than primary education ranges from 3.7 to 6.1 children per woman across twelve Latin American countries, whereas for women with at least secondary education the figure ranges from 1.7 to 2.6 (ECLAC 2011, 85). Finally, in female-headed households, many of these trends are exacerbated as women bear the burden of providing both income and care to their children without the help of a male partner.

\section{The Relevance of Issue-specific Typologies}

A vast literature on advanced industrialized countries addresses the way constellations of government policies influence both socioeconomic and gender inequalities. Esping-Andersen's (1990) influential classification of three worlds of welfare capitalism was based on eligibility criteria according to needs, contribution, or citizenship. In response to Esping-Andersen's initial neglect of gender, a large body of scholarly work emerged to address how states interact with families by promoting or discouraging the traditional division of labor between women and men, within the household and in the labor force. Regime typologies include Lewis' (1992) "strong male breadwinner" and "weak 
male breadwinner" types, Sainsbury's "universal breadwinner" and "individual" model (1996), Fraser's "breadwinner" versus "caregiver” model (1994), Gornick and Meyers' (2003) "dual-earner/dual-carer model," Misra, Budig and Moller's (2007) "earner," “carer," “choice," and "earner-carer" welfare state strategies, and Orloff's (2006) discussion of maternalism, among others. The basic gist of these typologies is the extent to which states promote gender equality by encouraging the employment of mothers and, more recently, the sharing of care responsibilities between parents (via provision of adequate parental and paternity leaves and full-time daycare) versus support for traditional families with the husband at work and wife at home (by scant provision of daycare and subsidization of stay-at-home mothers). With the continuing increase in women's labor force participation rates and below-replacement fertility in especially the most conservative countries in Europe, even hesitant governments have been jolted into action and are increasingly converging in the recognition that women will work outside the home, and need supportive policies if they are also to have children (see for example Morgan 2013). States still diverge in the extent to which they seek to involve fathers and the state in sharing care responsibilities.

Adapting Esping-Andersen's work to Latin America, previous research has identified the relative role that need, contribution, and citizenship play in people's access to social policy across the region (e.g. Filgueira 1998; Martínez Franzoni 2008; Pribble 2006). Filgueira's (1998) pioneering contribution stresses the socioeconomic bases of social policy regimes and distinguishes countries that achieved broad though segmented coverage (stratified-universal); exclusionary countries where social policies had very low coverage (exclusionary); and dual countries with a mix of the former in urban and rural areas, respectively (dual). Martínez Franzoni later incorporated unpaid work into the study of eighteen Latin American countries, developing a typology that takes into account the gendered basis of state and non-state, informal welfare regimes - where non-institutional forms of security provision, risk avoidance, and uncertainty management are more prominent than institutional formsin the region. ${ }^{7}$ The state welfare regimes have labor markets with a majority of formal salaried workers, low remittances, and robust social policy, while the informal welfare regimes have a majority of own account or migrant workers, high remittances, and rather weak social policy. The role the male-breadwinner family plays is less prominent under the latter than under the former. Transnational migration, scarce social investment, and high self-employment undermine the traditional male-breadwinner model, yet do not involve men or states in care responsibilities. In both typologies, the authors pay attention to informal labor relations and to the role of deep socioeconomic inequality, issues that set the region apart from advanced industrialized countries.

These typologies all provide valuable insights into tensions and interactions regarding the gendered basis for how markets and families are organized. They address eligibility criteria as mothers, workers, and citizens, and the implications such criteria have for female labor force participation. They have also 
been very useful in providing cross-national accounts regarding how welfare regimes shape traditional male-breadwinner families, dual-earner/dual-carer families, and gradations in-between. These typologies, however, focus on how states reshape social structures. Following Lowi's (1964) pioneering insight that determinants of policy formation are largely issue specific, the typology we present below is instead intended to help researchers account for the policy process. Lowi's fruitful distinction between regulatory, distributive, and redistributive policies has more recently been expanded to account for the uneven transformation of public policies fostering gender equity (Blofield and Haas 2011; Htun and Weldon 2010). A focus on regimes also makes it difficult to disentangle socio-economic and gender implications of policies, a point made by Hook (2006) when analyzing the determinants of men's unpaid work time.

Our typology thus contributes to comparative studies assessing specific policies and, therefore, specific angles to the reconciliation between paid and unpaid work (see for example Daly 2001; Jenson 1997; Kittilson 2008; Lambert 2008; Michel and Mahon 2002; Morgan 2009, 2013; Ray, Gornick, and Schmitt 2010; Weldon 2011) by disaggregating them into policy types and teasing out the implications for gender relations and social equity. Our typology also provides a useful basis from which to develop both intra- and interregional comparisons.

\section{Conceptualization}

Policies that reconcile paid work and family responsibilities can range from measures that help women plan if, when, and how many children to have; to labor policy that sets rules for hiring, working hours, remuneration, promotion, and firing employees; to policies toward urban planning and public transportation. Rather than risk losing all analytical leverage by having too broad of a focus, here we focus on "the tip of the iceberg" of reconciliatory policies, namely, those that specifically revolve around paid work and childbirth and childrearing at an early age.

We begin by laying out three types of policies that reconcile paid work and family responsibilities depending on how they intervene in the interaction between the two. Policies may come in the form of sequential measures; they may transfer some unpaid work outside the family (i.e., defamilializing) and/ or formalize home-based paid care (i.e. regulatory policies). We then explain our understanding of how they maintain or reshape the initial stratification along socio-economic and gender lines. ${ }^{8}$ We then look at examples of specific policies in terms of how they reshape either one.

\section{Policies That Reconcile Work and Family}

First, the kinds of policies we consider to be within the broad category of work-family reconciliation policies are those that provide time, income support, and/or services to families. They are therefore at the crossroads of 
various policy domains, from labor to social policy and, within social policy, they include family, gender, and care policies. Most of these policies were neither explicitly designed nor adopted to reconcile work and family responsibilities. This is as much the case for maternity leaves, meant to protect income security while working mothers recover from childbirth, as it is for preschool education which is primarily conceived as promoting equal opportunities and human capital of children.

We are interested in how policies actually alter work-family relationspositively or negatively for social and gender equity, among families with young children. These policies can shape work and family relations in at least three different ways: by sequencing work and care responsibilities while maintaining care provision within the family (Durán 2004); by shifting care responsibilities from families toward markets and states, therefore by defamilializing care (see Martínez Franzoni 2008 and Orloff 2009: 320 (fn 6) for a discussion of this concept), and by regulating the labor standards of home-based care services (Lund 2010; Meena 2010 in Cook and Razavi (2012). ${ }^{9}$ We thus classify work-family policies into three types: sequential, defamilializing, and regulatory. ${ }^{10}$

Sequential policies refer to income support policies so that breaks for caregiving do not threaten people's income security. They include maternity, paternity and parental leave policies, flexible work time policies, and policies toward part-time work. The sequencing can last months and involve many work days (as in maternity leave) or last hours within a single work day or week (as in part-time or flexible work time measures). These policies have traditionally focused on women and initially had goals other than reconciling work and family such as protecting the health of the mother and baby but have increasingly included men. With sequential policies, caregiving remains the responsibility of the family.

Policies that defamilialize care refer to benefits (both transfers and services) that shift the responsibility for care provision from families and women to the state, either in the form of direct public provision, in the form of funding private provision, or in the form of laws for employer provision or tax incentives or subsidies for market provision. They include employer mandates on childcare services, public or subsidized provision of early childhood education and care (ECEC), extension of school days, and after-school programs. Eligibility for many services, on educational grounds, has been based on the child. Beyond this, these measures often revolved around mothers and female workers, but have increasingly begun to make men and fathers eligible as well. They specifically assume that mothers are not infinitely available to work in unpaid care labor at home, and that all adult members of a household may be in the labor market.

In sequential policies, labor regulations toward workers as parents are a central element. However, they can also be relevant with defamilializing policies, as personnel involved in care services contribute to coping with tensions 
between paid work and family responsibilities through the services they provide. Thus within the category of defamilializing policies one could also examine the labor conditions of care providers.

Our third category addresses regulations toward the hiring of home-based paid care providers specifically, where the household is turned into a work site. Here, government regulatory policies toward home-based care occupations become important. We are particularly interested in "unskilled" ${ }^{11}$ paid domestic work although the analysis can equally be extended to skilled health-related occupations crucial for elder care, such as nurses. The one-to-one hiring of mostly female personnel for work in familial settings is an alternative to public provision in institutional settings as happens through measures that defamilialize care. Given that these are not usually included under reconciliation policies between paid work and family responsibilities, we explain our rationale for doing so.

As with other care occupations, home-based care tends to be overwhelmingly female and subjected to a "care penalty." This care penalty, which reduces the remuneration that workers in such occupations receive vis-à-vis comparably skilled occupations, derives from three factors: care occupations have historically been seen as extensions of naturalized female roles; they are perceived as intrinsically rewarding; and, as "sacred activities", less appropriate for financial recognition (England and Folbre 1999). Provided that care (paid and unpaid) involves an emotional connection between caregivers and those cared for, labor market regulations regarding these care occupations are critical to the status of the care providers as workers and to the type of service performed (see for example Folbre 1995, ${ }^{12}$ Williams 2010).

What makes home-based care occupations distinct is that the workplace and the household overlap and that the bonds between caregivers and care-receivers tend to be more personal, challenging the regulation of these occupations. Unskilled home-based care in the employer's household-paid domestic work - has long been devalued and is associated with a servant culture in many countries. This arrangement has thus occupied a gray area between paid and unpaid work. Legal discrimination has been enshrined in laws and labor codes, with long work hours and limited labor protections and benefits. What makes this category empirically so central is its dominance as a mode of care resolution in highly unequal countries. In Latin America, just over 15 percent of the economically active female population is employed in domestic service, with a similar percent of households as employers (ECLAC 2012; OIT 2012: 59-60). ${ }^{13}$ If the state reinforces this status quo it is effectively subsidizing the reconciliation of work and family responsibilities for the well to do, but at the cost of such reconciliation for these female workers (Blofield 2012).

Another, more collective form of home-based care (also referred to as family day care) is care in the caregiver's household. While such care has no doubt informally existed throughout time, it has more recently-since the 1990s- 
become an object of government funding and regulation as part of social service extension to low-income families in the context of state retrenchment.

Sequential and defamilializing policies, as well as regulations of home-based paid care, are all qualitatively distinct and tap into a separate element of workfamily reconciliation. More policy in one dimension/type does not make up for less policy in another dimension/type. At the same time, it is possible to examine how the policies interact with one another. For instance, loose regulations regarding one specific type of care occupation, paid domestic work, lower the probability that middle-income families will voice demands for public provision of defamilializing policies. By the same token, one specific type of sequential policy, extended maternity leave, makes services less pressing by way of relying on mothers as primary caregivers beyond the nursing period.

\section{Implications for Social and Gender Equity}

Depending on their characteristics sequential, de-familializing, and regulatory policies reallocate time, income support and services in ways that can either reinforce or positively alter social stratification along social and gender lines. The former alters or reinforces the market's allocation of resources, while the latter reinforces or alters the sexual division of labor between women and men.

In terms of gender equity, we assess how government policies address sexbased norms and expectations (i.e. gender roles). While our analysis focuses on policies and sub-dimensions of policies rather than regimes, the insights of the gender and welfare state literature mentioned above form the basis of a typological distinction between "maternalist" policies and policies that promote "co-responsibility" (UNDP/ILO 2009). We also specify a "maternalist floor" that acknowledges the specific role of women in giving birth and breast feeding.

Co-responsibility policies seek to involve governments and men in caregiving in recognition of women's role as workers, not only as mothers, thus distributing responsibility away from a sole reliance on mothers. We can distinguish between policies that promote state co-responsibility and policies that promote paternal co-responsibility within the family. State co-responsibility policies involve defamilialization through provision of public or subsidized private ECEC with opening hours that correspond to a full-time work day thus allowing for the use of this service as a mode of care resolution for working parents. ECEC services that are only viewed as an educational service for child development, with opening hours that may be half-time, or do not correspond to a full-time workday, defamilialize but do not promote state co-responsibility in workfamily reconciliation (although they do promote state co-responsibility in child education).

Paternal co-responsibility policies promote sharing of caregiving by incentivizing fathers' involvement. ${ }^{14}$ They are sequential policies that promote the reorganization of gender roles among parents. Both types of policies, by sharing caregiving more equitably across men, women, and states, seek to reduce the gender gap in caregiving and the labor market. They tend to reduce gender 
discrimination in the labor force that results from the traditional gender division of labor in caregiving responsibilities. ${ }^{15}$

Some policies recognize and reward care as a female responsibility without seeking to reduce the gender gap per se. We refer to these types of policies as "maternalist" (Orloff 2006). Maternalist policies recognize the importance of caregiving and "exalt women's capacity to mother" (Koven and Michel 1993: 4, quoted in Orloff 2006) while making it solely or primarily women's responsibility. ${ }^{16}$ Maternalist policies are different from policies that establish what we call a "maternalist floor" that acknowledges the role of women in giving birth and breast feeding such as maternity leave that helps women recover physically and emotionally and to establish routines and bonds with the newborn. In contrast, generous maternity leaves or a tax incentive or a cash transfer for stay-at-home mothers can be considered maternalist. The demarcation between the two is not fixed but has changed over time. For example, in 1952 for the ILO regular maternity leaves involved twelve weeks (as established in agreement 103) but by 2000 this had increased to fourteen weeks (agreement 183).

If we understand and define gender equity to be reducing the differences between women and men associated with socially constructed gender roles, then maternalism can have contradictory effects. On the one hand, such policies publicly acknowledge and support motherhood as a central dimension of women's lives and can thus elevate the status of mothers. A maternalist floor such as a short-term maternity leave is essential to enable mothers to recuperate from childbirth without losing their jobs. However, maternalist policies beyond this can reinforce the notion that care is women's sole responsibility. It is an empirical matter to establish which maternalist policies also promote gender equity by leveling the playfield rather than reinforcing the sexual division of labor.

In terms of social equity, we follow Esping-Andersens's (1990) distinctions between eligibility based on needs, contribution, or citizenship. His analysis, however, assumes the dominance of formal labor markets which is not the case in Latin America. Therefore, benefits extended to formal workers have a different kind of distributive dynamic. Such policies tend to restrict benefits to those making regular contributions as well as their dependents-often even segmenting benefits between the former and the latter. They primarily benefit middle- and upper-income groups of the population, therefore reinforcing socioeconomic inequities. ${ }^{17}$ Policies based on contributions tend to also reinforce inequities between groups within the formal labor force, for example, workers on fixed-term contracts and paid domestic workers may not legally have access to the same rights. Taking into account the prominence of informal relations in Latin American labor markets, we assess policies on whether they extend protections to a broader scope of salaried workers (e.g. temporary and domestic workers) who may work under formal or informal arrangements and beyond salaried workers to self-employed workers. ${ }^{18}$ We also assess policies in terms of whether they are based on citizenship or need. If either of the latter is 
the case, we consider that work-family policies alter the initial, market stratification and therefore also enhance social equity. ${ }^{19}$

Social and gender inequalities are intertwined at the intersection of the labor market and care. Informality may pervade care arrangements either through the informal contracting of domestic workers or through female unpaid care work. Without government intervention, the care burden tends to fall particularly heavily on low-income women, as degrees of "familialisation" of care (Orloff 1996) differ markedly by income levels. While upper middleand upper-class women can avoid having to negotiate the sharing of household responsibilities with their male partners by outsourcing much of the domestic responsibilities to lower-income women, high socioeconomic inequalities and discriminatory regulatory policies toward paid domestic work reinforce this burden for low-income women.

Given these interactions, it is inaccurate to subsume one type of inequality under another or privilege one over the other; we must examine their interaction across distinct policy initiatives.

Each of the policies we focus on-sequential, defamilializing, and regulatory-may have various implications for social and gender stratification. Regarding gender, we establish whether specific measures promote a maternalist floor, maternalism, or paternal or state co-responsibility. Regarding social equity we address whether or not they extend labor market protections, transfers, or services beyond a restricted group of salaried workers, either to more groups of workers such as own-account or temporary workers, or on the basis of need or citizenship. Since measures may simultaneously reshape both gender and social equity, we look at their intersection as well.

\section{Putting our Categories to Use}

In this section, we put to use the typology we propose. For each policy type we address social and gender equity-enhancing effects. To simplify the format and discussion of the three tables that follow, we only list categories that are relevant for each policy type.

Table 1 focuses on paid leaves broken down according to their implications for securing a maternalist floor, promoting maternalism or promoting paternal co-responsibility, and promoting social equity. ${ }^{20}$ We divide leaves into three categories: maternity leave, paternity leave, and parental leave. With regard to maternity leave, we consider the ILO standard of fourteen weeks to be the maternalist floor that allows a woman to recuperate after birth, start breast feeding, and establish a bond. Maternity leaves beyond this standard we consider maternalist. Extended maternity leaves can be positive in many ways (for example, for breast feeding) but do not contribute to paternal co-responsibility since they do not allow for or encourage reorganizing the distribution of caregiving between women and men. 
Table 1. Equity-enhancing effects of sequential policies: employment-based paid leaves

\begin{tabular}{|c|c|c|c|}
\hline \multirow{2}{*}{$\begin{array}{l}\text { Policy } \\
\text { measure }\end{array}$} & \multicolumn{3}{|c|}{ Equity-enhancing effects } \\
\hline & Maternalist floor & Maternalism & Paternal co-responsibility \\
\hline $\begin{array}{l}\text { Maternity } \\
\text { leave }\end{array}$ & $\begin{array}{l}\text { Maternity leave } \\
\text { according to ILO } \\
\text { standard of } 14 \\
\text { weeks }^{\text {a }}\end{array}$ & $\begin{array}{l}\text { If maternity leave } \\
\text { extends beyond } \\
\text { ILO standard }\end{array}$ & $\begin{array}{l}\text { If leave beyond ILO standards is } \\
\text { shareable by parents }\end{array}$ \\
\hline $\begin{array}{l}\text { Paternity } \\
\text { leave }\end{array}$ & $\begin{array}{l}\text { Paternity leave } 1-5 \\
\text { days to assist } \\
\text { women upon } \\
\text { delivery }\end{array}$ & If none beyond this & $\begin{array}{l}\text { If paternity leave extends } \\
\text { beyond } 5 \text { days, with explicit } \\
\text { goal to support male role as } \\
\text { caretakers }\end{array}$ \\
\hline $\begin{array}{c}\text { Parental } \\
\text { leave }\end{array}$ & - & - & Any shareable parental leave \\
\hline
\end{tabular}

Source: own elaboration.

${ }^{a}$ Convention 103 in 1952 had established twelve weeks which were extended to fourteen in 2000.

Paternity leaves are not addressed in international agreements. We consider paternity leaves of one to five days, established to allow fathers to accompany mothers as they recover from delivery, as providing a maternalist floor. Any paternity leaves beyond this we consider as promoting co-responsibility. While six days or more is not particularly extensive, such leaves do take a step beyond the recognition that fathers are only needed to basically help mothers get home from the hospital. ${ }^{21}$

Parental leaves are leaves that allow for sharing and thus also promote paternal co-responsibility. They follow maternity and/or paternity leaves. They are not established in any ILO agreement either. However, two recommendations, 191 and 165, which accompany Agreements 183 and 165 on maternity protection and workers with family responsibilities, respectively, do refer to them. Any leaves that are shareable between mothers and fathers we consider as promoting co-responsibility - the more the sharing itself is made part of the bargain through incentives to encourage fathers to take at least a part of it, the better for co-responsibility. Finally, all these measures may be restricted to some salaried mothers and/or fathers in the formal sector; reach all salaried workers (including paid domestic workers) and/or informal and/or temporary workers; and/or reach parents on the basis of need or as a right. The first reproduce while the latter promote social equity.

The commitment of the state to provide care services can take several forms, from regulation to funding and direct provision, whether via public or 
Table 2. Full-time ECEC services (state co-responsibility): Equity-enhancing effects of eligibility criteria

\begin{tabular}{|c|c|c|c|}
\hline \multirow[b]{3}{*}{ Policy measure } & \multicolumn{3}{|c|}{ Equity-enhancing effects } \\
\hline & \multicolumn{2}{|l|}{ Gender equity } & \multirow[b]{2}{*}{ Social equity } \\
\hline & $\begin{array}{l}\text { Maternalist } \\
\text { criteria }\end{array}$ & $\begin{array}{l}\text { Paternal } \\
\text { co-responsibility }\end{array}$ & \\
\hline $\begin{array}{l}\text { Employer } \\
\text { mandates }\end{array}$ & $\begin{array}{l}\text { Services } \\
\text { restricted to } \\
\text { mothers }\end{array}$ & $\begin{array}{l}\text { Services available to } \\
\text { mothers and fathers }\end{array}$ & $\begin{array}{l}\text { Services reach } \\
\text { beyond large } \\
\text { business firms }\end{array}$ \\
\hline $\begin{array}{l}\text { Public or } \\
\text { subsidized } \\
\text { services }\end{array}$ & $\begin{array}{l}\text { Services } \\
\text { restricted to } \\
\text { mothers }\end{array}$ & $\begin{array}{l}\text { Services available to } \\
\text { mothers and fathers }\end{array}$ & $\begin{array}{l}\text { Services on the basis } \\
\text { of need or } \\
\text { citizenship }\end{array}$ \\
\hline
\end{tabular}

Source: own elaboration.

subsidized provision, or via employer mandates. Provision of services that correspond to full-time working hours is an indicator of state co-responsibility in work-family reconciliation. State co-responsibility as here defined will thus have an equity-enhancing effect on gender relations. Beyond this, full-time ECEC services can have additional implications for gender and social equity, as outlined in Table 2. In Table 2, we classify services that are restricted to mothers as having maternalist criteria, while services for which fathers are also eligible as encouraging paternal co-responsibility. In addition, these services may reach formal employees alone or reach other people as well-e.g. people living in the same geographical areas in which the firm is based. Socioeconomic implications of these arrangements are not equity enhancing in the first case but can be in the second if eligibility criteria are either universal or means-tested.

Some countries (for example, Chile and Brazil) seek to provide some care services via employer mandates on large businesses. Such mandates transfer care responsibilities from the mother to the employer during the work day but if such mandates are established only for women and on the basis of the number of women employed (as in Chile and Brazil), they also reinforce the idea that caregiving is solely the female worker's responsibility. This can increase employers' propensity to discriminate against women in hiring decisions. As such, these policies may actually aggravate the gender gap in the labor force by encouraging employer discrimination against women. ${ }^{22}$ Theoretically, mandated employment-based care could allow or encourage use by fathers but to our knowledge no such cases exist in Latin America. 
Finally, services for which parents or children qualify on the basis of need or citizenship - not on the basis of formal employment or other such restrictive criteria-we classify as promoting social equity. Some services may promote social equity via maternalist criteria, for example, subsidized services available to mothers employed in the informal sector, or to all low-income mothers.

Policies mandating that large businesses provide daycare tend not to enhance social equity unless they have a large share of unskilled workers or unless they reach people beyond the firm on the basis of need or citizenship. Since large firms tend to be a tiny minority, state-provided services based on needs or citizenship have a much more positive effect on social equity than employment-based services. Hence, we classify such policies as not promoting social equity unless they extend to smaller businesses (which may have other complicated effects, which is likely why such mandates do not exist).

Table 3 outlines the equity-enhancing effects of regulations on home-based care.

We distinguish two types of home-based care services that can be targets of government regulation: paid domestic workers, who perform their tasks in their employer's household, and caregivers who provide childcare services in their own home. As mentioned above, while the former tends to be more established in labor laws and codes, given its deep roots as a form of service for elites, the latter has more recently become an object of attention in Latin America for government regulation in the attempt to expand care services to low income families and children (ILO/UNDP 2009).

Table 3. Equity-enhancing effects of regulatory policies on home-based care-providers

\begin{tabular}{clll}
\hline & Equity-enhancing effects & \\
\cline { 2 - 4 } Policy measure & Maternalist floor & Maternalism & Social equity \\
\hline $\begin{array}{c}\text { Paid domestic } \\
\text { workers }\end{array}$ & $\begin{array}{c}\text { Equal legal rights } \\
\text { regarding } \\
\text { maternity leaves }\end{array}$ & $\begin{array}{c}\text { Certification of care } \\
\text { skills derived from } \\
\text { motherhood (as } \\
\text { distinct from } \\
\text { domestic chores) }\end{array}$ & $\begin{array}{l}\text { Equal legal rights } \\
\text { regarding working } \\
\text { hours and wages in } \\
\text { labor law/codes }\end{array}$ \\
$\begin{array}{c}\text { Collective } \\
\text { caregivers in } \\
\text { care } \\
\text { provider's } \\
\text { home }\end{array}$ & $\begin{array}{c}\text { Equal legal rights } \\
\text { regarding } \\
\text { maternity leaves }\end{array}$ & $\begin{array}{c}\text { Fung and/or } \\
\text { certification of female } \\
\text { home-based care }\end{array}$ & $\begin{array}{l}\text { Equal legal rights } \\
\text { regarding working } \\
\text { hours and wages } \\
\text { compared to } \\
\text { reference group } \\
\text { (e.g. school }\end{array}$ \\
& & & teachers)
\end{tabular}


Overall, as workers in both types of home-based care occupations are overwhelmingly female, policies that promote social equity in providing equal labor rights for these workers are also positive for gender equity. In contrast, policies that promote lower protections for these care workers, due to the "care penalty" in general (England and Folbre 1999) and elite biases toward domestic service in particular (Blofield 2012), can aggravate the gender gap in the labor market and thus social inequity as well. More generally, policies that encourage these types of service provision in lieu of encouraging collective, institutionalized forms of care tend to reinforce both types of inequities.

Within this context, policies that provide maternity leave provide a maternalist floor to these workers. When they encourage or mandate the certification/ formalization of care-related skills associated with motherhood (as opposed to other skills related to the services they provide), or only consider or assume females in these roles, they promote maternalism. (Given that workers are overwhelmingly female in care occupations, paternal co-responsibility is not a relevant category here.)

\section{Implications}

The study of policies that reconcile work and family poses a challenge of categorization, first, because they may be either social or labor market policies and because they were not necessarily intentionally designed to reconcile paid work and family responsibilities. Here, we have sought to delineate meaningful policies by focusing on the reallocation of time, services, and regulation between unpaid and paid care. We draw on some key policy measures central to reconciling paid and unpaid work, rather than aiming to include all relevant measures. Indeed, further analysis can draw on empirical evidence concerning key labor and social policy for each policy type involved. This is one reason why we choose to refer to how each policy type intervenes in the tension between paid work and family responsibilities.

Our goal has been to provide a conceptual lens that acknowledges the complex set of challenges involved in reconciling work and family and that, accordingly, brings a myriad of different policies under one broad umbrella. In addition to classifying policies by type-sequential, defamilializing, and regulations of home-based care-this approach allows us to disaggregate the implications for social equity and gender relations across policies. Although beyond the scope of this paper, it makes it possible to examine the causal factors behind each policy, in line with a robust literature showing that when it comes to gender equity and to worf-family policy specifically, causal processes tend to be issue-specific (Blofield and Haas 2005, 2011; Htun and Weldon 2010; Kittilson 2008; Lambert 2008; Mazur 2002; Michel and Mahon 2002).

By disaggregating each policy's implications for gender and social equity, this typology allows researchers to avoid conflating the two. Also, the way we propose to measure social equity enables scholars to accurately assess the 
implications of policies in countries with large informal labor markets, an issue that typologies based on advanced industrialized countries tend to ignore. An extension of paternity leave for salaried workers in any European country will have more progressive distributive implications along socioeconomic lines than an extension of paternity leave for salaried workers in any Latin American country. By the same token, an extension of maternity leave to non-salaried workers in Latin America will have a more progressive distributive implication along socio-economic lines than the same leave in Europe. Our typology allows for systematic comparative analysis of both small and large numbers of countries, and allows for cross-regional analysis as well. Comparisons may focus on policy outcomes, namely gender and social equity, as well as one or more policy types. This is particularly useful to assess policy change when measures may have intended and non-intended, often even contradictory consequences.

In terms of policy outcomes, while our goal has been to disaggregate policies, we recognize that once this is done, it is also important to 're-aggregate', so to speak, and empirically examine how policy constellations interact with one another and how they interact with the actual composition of families and labor markets. This, of course, has been one of the key insights of the regime typology literature.

Our typology can also be used to examine the different stages of the policy cycle. For example, a policy may be maternalist in its framing and design but, given the broader socioeconomic and political context, have effects that also promote paternal or state co-responsibility. In other words, interactions across policy stages need to be empirically determined. The proposed typology will have served its purpose if it nourishes cross-national and cross-issue empirical analysis.

\section{Notes}

Authors are thankful to the journal's editor as well as to anonymous reviewers for their generous and thoughtful inputs in the first round of reactions. We are also grateful to Reviewer 2's second round of comments which helped us clarify our argument. Both the authors have equally contributed in this manuscript.

Her area of research is comparative politics, with a specialization in Latin American politics and gender and politics. Blofield has published two-singleauthored books and one edited volume. Her most recent book is Care Work and Class: Domestic Workers' Struggle for Equal Rights in Latin America (Pennsylvania State University Press, 2012). Among others, she has published in Comparative Politics and Latin American Research Review, and has directed projects funded by the Ford Foundation (2007-2009) and Fundação de Amparo à Pesquisa do São Paulo (2012). Her current research is on work-family policies in Latin America.

Her work on social policy formation and socioeconomic and gender inequality in Latin America has most recently been rewarded with fellowships by Fulbright, the Kellogg Institute for International Studies and the British Academy. She currently conducts research on the formation of universal social policies in the 
periphery and policy changes in work-family policies in Latin America. Her most recent book is "Good Jobs and Social Services: How Costa Rica Achieved the Elusive Double Incorporation" co-authored with Diego Sánchez-Ancochea (Palgrave, Forthcoming). ${ }^{\star}$ Name order is alphabetical; both authors are equal contributors.

1. In empirical terms, in this article the region comprises eighteen countries: Brazil and all the Spanish speaking countries. In the case of UN data, Cuba is generally excluded for lack of comparable household survey data.

2. While income inequalities have increased lately in advanced industrialized countries as contrasting as the United States and Sweden, the average Gini coefficient among the OECD countries is still only 0.31 (including Chile and Mexico which have high income inequality) whereas for Latin America it is above 0.50 (OECD 2011; SEDLAC 2011).

3. A broad array of public policy can have indirect yet very tangible effects upon work/family relations, from urban planning and public transportation to in kind transfers like nutrition programs and school uniforms (Monge 2006). Here, we use a restrictive definition focused on measures that directly alter the organization of care, therefore reorganizing work and family relations.

4. Care of disabled and elderly can elicit similar tensions; here we focus on young children but our framework could potentially be used for other kinds of dependent care as well.

5. See for example Portes and Hoffman 2003; Lindert, Skoufias, and Shapiro 2006; Huber, Pribble, and Stephens 2009; Díaz-Cayeros and Magaloni 2010; Filgueira 2011.

6. This is the case for most of the self-employed and salaried workers in businesses with five employees or less which are the majority of the labor force.

7. For the pioneering elaboration on the notion of informal welfare regimes in the global South, see Gough and Wood (2004).

8. Some may prefer to label these policy types as time, services, and regulation of paid care work. We instead prefer the categories as proposed. We think it is more useful to rely on analytic categories that give room to look at a broad set of empirical measures in light of how they specifically intervene in the relation between paid and unpaid work.

9. The notion of home-based care initially referred to services created in response to HIV and AIDs in the African context. Such services were voluntary and therefore distinct from paid domestic work. Cook and Razavi (2012) refer to home-based services as different from (institutional) responses reflected in early child education and services. Here we take the notion of home-based care at face value, that is, as taking place in the household.

10. Martinez Franzoni and Camacho $(2006,2007)$ made a first exploratory attempt at drawing on Durán's work to conduct an empirical policy assessment.

11. By "unskilled" we mean that these employees rarely have formal training for their occupations, although they provide services that require a lot of practical and undervalued skills.

12. Folbre (1995) defines "caring labor", whether paid or unpaid, as work that involves connecting to other people and trying to help people meet their needs. This involves activities like the work of caring for children, caring for the elderly, 
caring for sick people, or teaching. Folbre argues that the intrinsic motivation involved in care labor as something people do for a third party poses challenges for markets to organize and pay for care work.

13. Paid domestic work has also gained relevance in the more developed countries as global care chains expand across the planet (Hohschild 2001).

14. Fraser (1997) refers to such policies, broadly, as "dedifferentiating" social groups by undermining group differences (in this case, by abolishing the gendered division of labor), and Esping-Andersen as "feminizing the male life cycle" (2009: 99).

15. Note that here we do not address policies that focus on sex discrimination per se in the labor force, which occurs when an individual is "treated less favorably on grounds of sex than another is, has been or would be in a comparable situation" (Prechal and Burri 2009: 4). We address gender-based discrimination in caregiving responsibilities that arises from structural differences related to gender roles that result in different outcomes for women and men (for an overview see Blofield and Haas 2013).

16. Historically, maternalist movements "made arguments for gender justice: women should be recognized and compensated by the state for their unique contribution to society-through maternity and childrearing" (Orloff 2006:10) Orloff (2006) argues that in European and North American countries, maternalist claims have lost elite and popular support over time, although not always in the direction of more gender equity but rather in the direction of less social equity.

17. For a discussion of the relevant cases where universalism has been built around contributory policy see Martínez Franzoni and Sánchez-Ancochea (2014).

18. In Latin America labor and social protections reach workers in various degrees, giving way to a continuum from the most formal to the most informal arrangements among salaried workers as well as the self-employed. Rather than giving shape to an informal "sector" informality thus becomes a feature that cuts across the labor market.

19. See Pribble (2013) for a broader discussion of equity-enhancing social policies.

20. The replacement rate of paid leaves ranges across countries and regions. In Latin America, paid leaves tend to be reimbursed at 100\% although with wage ceilings in some cases.

21. In addition, these leaves have been passed as part of the most recent wave of policy reforms and have involved issue framing and political dynamics that deserve attention.

22. Such care services also tend to be mandated only for the period in which the mother is expected to breastfeed, and hence are not a broader solution to childcare needs.

\section{References}

Blofield, Merike. 2012. Care work and class: Domestic workers' struggle for equal rights in Latin America. University Park, PA: Penn State Press.

Blofield, Merike, and Liesl Haas. 2005. Defining a democracy: Reforming the laws on women's rights in Chile, 1990-2002. Latin American Politics and Society, 47 (3): $35-68$. 
Blofield, Merike, and Liesl Haas. 2011. Gender equality policies in Latin America. In The great gap: Inequality and the politics of redistribution in Latin America, ed. M. Blofield. College Park, PA: Pennsylvania State University Press.

. 2013. Policy outputs. In Oxford handbook on gender and politics, eds. Karen Celis, Johanna Kantola, Georgina Waylen, and Laurel Weldon. Oxford: Oxford University Press.

Blofield, Merike, and Regina Madalozzo. 2013. Conciliação entre Família e Trabalho nas Famílias de Classe Média-Baixa e Baixa em São Paulo. Congresso Latino-Americano de Estudos do Trabalho, July 4, 2013, São Paulo.

Chioda, Laura. 2011. Work \& family: Latin American and Caribbean women in search of a new balance. Washington, DC: The International Bank for Reconstruction and Development.

Cook, Sarah, and Shahra Razavi. 2012. Work and welfare: Revisiting the linkages from a gender perspective. UNRISD Research Paper No.2012-7 December.

Cornia, Andrea. 2010. Income distribution under Latin America's New Left Regimes. Journal of Human Development and Capabilities, 11 (1): 85-114.

Daly, Mary. 2001. Care policies in Western Europe. In Care work: The quest for security, ed. Mary Daly, 33-56. Geneva: International Labour Organisation.

Díaz-Cayeros, Alberto, and Beatriz Magaloni. 2010. La ayuda para los pobres de América Latina. Journal of Democracy en Español, 2 185-200.

Durán, María-Ángeles. 2004. ¿Cómo conciliar trabajo y vida familiar? Un desafío colosal. Retrieved December 06, 2012, from: http://www.comfia.info/index.php?modo= leer\&art $=14814$.

Economic Commission for Latin America and the Caribbean (ECLAC). 2009, 2010, 2011 and 2012. Social Panorama of Latin America. Santiago de Chile: ECLAC.

England, Paula, and Nancy Folbre. 1999. The cost of sharing. Annals of the American Academy of Political and Social Science, 561 (1): 39-51.

Esping-Andersen, Gøsta. 1990. The three worlds of welfare capitalism. Cambridge: Polity Press.

. 2009. The incomplete revolution: Adapting to women's new roles. Cambridge: The Polity Press.

Filgueira, Fernando. 1998. El nuevo modelo de prestaciones sociales en América Latina: residualismo, eficiencia y ciudadanía estratificada. In Ciudadanía y políticas sociales, ed. Roberts Brian, 32-73.

. 2011. Fault lines in Latin American social development and welfare regime challenges. In The great gap: Inequality and the politics of redistribution in Latin America, ed. Merike Blofield, 21-57. College Park, PA: Pennsylvania State University Press.

Filgueira, Fernando, Luis Reygadas, Juan Pablo Luna, and Pablo Alegre. 2011. Shallow states, deep inequalities and the limits of conservative modernization: The politics and policies of incorporation in Latin America. In The great gap: Inequality and the politics of redistribution in Latin America, ed. Merike Blofield. College Park, PA: Pennsylvania State University Press.

Folbre, Nancy. 1995. "Holding hands at midnight": The paradox of caring labor. Feminist Economics, 1 (1): 73-92.

Fraser, Nancy. 1994. After the family wage: gender equity and the welfare state. Political Theory, 22:591-618. 
1997. Justice interruptus: Critical reflections on the "Postsocialist" condition. London: Routledge.

Gornick, Janet, and Marcia Meyers. 2003. Families that work. New York: Russell Sage Foundation.

Gough, Ian, and Geof Wood. 2004. Introduction. In Insecurity and welfare regimes in Asia, Africa and Latin America: Social policy in development contexts, ed. Ian Gough, and Geof Wood, 1-14. Cambridge, MS: Cambridge University Press.

Hohschild, Arlie. 2001. The Nanny chain. The American Prospect, December 19, available at http://prospect.org/article/nanny-chain.

Hook, Jennifer L. 2006. Care in context: Men's unpaid work in 20 countries, 19652003. American Sociological Review, 71:639-60.

Htun, Mala, and Laurel Weldon. 2010. When do governments promote women's rights? A framework for the comparative analysis of sex equality policy. Symposium: A Comparative Politics of Gender, 8 (1): 207-16.

Huber, Evelyne, Jennifer Pribble, and John D. Stephens. 2009. The politics of effective and sustainable redistribution. In Stuck in the middle: Is fiscal policy failing the middle class? eds. Antonio Estache, and Danny Leipziger, 155-88. Washington, DC: Brookings Institution Press.

International Labour Organization. 2009, 2011 and 2012. Panorama laboral. Lima, Peru: International Labour Organization.

Jenson, Jane. 1997. Who cares? Gender and welfare regimes. Social Politics, 4 (2): 182-7.

Kittilson, Miki Caul. 2008. Representing women: The adoption of family leave in comparative perspective. The Journal of Politics, 70 (2): 323-34.

Koven, Seth, and Sonya Michel. 1993. Mothers of a new world: Maternalist politics and the origins of welfare states. New York: Routledge.

Lambert, Priscilla A. 2008. The comparative political economy of parental leave and childcare: Evidence from twenty OECD countries. Social Politics, 15 (3): 315-44.

Lewis, Jane. 1992. Gender and the development of welfare regimes. Journal of European Social Policy, 2:159-73.

Lindert, Kathy, Joseph Skoufias, and Joseph Shapiro. 2006. Redistributing income to the poor and the rich. Washington: World Bank.

López-Calva, Luis F., and Nora Lustig, eds. 2010. Declining inequality in Latin America: A decade of progress? Washington, DC: Brookings Institution Press.

Lowi, Theodore. 1964. Public policy, case-studies, and political theory. World Politics, 16 (4) (Jul., 1964):677-715.

Lund, Francie. 2010. Hierarchies of care work in South Africa: Nurses, social workers and home-based care workers. International Labour Review Special Issue: Workers in the Care Economy, 149 (4): 495-509.

Martínez Franzoni, Juliana. 2008. Welfare regimes in Latin America: Capturing constellations of markets, families and policies. Latin American Politics and Society, 50 (2): 67-100.

Martínez Franzoni, Juliana, and Rosalía Camacho. 2006. Género, políticas conciliatorias y presupuesto público: una aproximación al caso de América Latina y el Caribe. In Cohesión social, políticas conciliatorias y presupuesto público. Una mirada desde el género, eds. Luis Mora, María José Moreno, and Tania Rohrer, 261-301.

- 2007. Equilibristas o malabaristas. .., pero con red? La actual intraestructura de cuidados en América Latina. In Entre familia y Trabajo, eds. Carbonero Gamundí, and Levin, 117-46. 
Martínez Franzoni, Juliana, and Diego Sánchez-Ancochea (2014). Filling the missing link between universalism and democracy: the case of Costa Rica. Latin American Politics and Society. Fall. Forthcoming.

Martínez Franzoni, Juliana, and Koen Voorend. 2009. Sistemas de patriarcado $y$ regímenes de bienestar en América Latina: ¿una cosa lleva a la otra? Documento de trabajo número 27. Madrid: Fundación Carolina.

- 2011. Are coalitions equally important for redistribution in Latin America? The intervening role of welfare regimes. In The great gap, ed. M. Blofield, 348-76.

Mazur, Amy. 2002. Theorizing feminist policy. New York, NY: Oxford University Press.

Meena, Ruth. 2010. Nurses and home-based caregivers in the Republic of Tanzania: A discontinuum of care. International Labour Review Special Issue: Workers in the Care Economy, 149 (4): 529-42.

Michel, Sonya, and Rianne Mahon. 2002. Child care policy at the crossroads: Gender and welfare state restructuring. New York: Routledge.

Misra, Joya, Michelle J. Budig, and Stephanie Moller. 2007. Reconciliation policies and the effects of motherhood on employment, earnings and poverty. Journal of Comparative Policy Analysis, 9 (2): 135-55.

Molina, Gerardo. 2006. Universalismo básico. Una nueva política social para América Latina editor. Washington, DC: Inter-American Development Bank.

Monge, Guillermo. 2006. "Igualdad de género, pobreza y políticas de conciliación entre los ámbitos productivo y reproductivo y presupuestos públicos: Un análisis de cinco países latinoamericanos." UNFPA/Proyecto "Política fiscal con enfoque de género de la cooperación técnica alemana (GTZ).” México, D.F.

Morgan, Kimberly J. 2009. Caring time policies in Western Europe: Trends and implications. Comparative European Politics, 7 (1): 37-55.

Morgan, Kimberly. 2013. Path shifting of the welfare state: electoral competition and the expansion of work-family policies in Western Europe. World Politics, 65 (1): $73-115$.

OECD. 2011. Why inequality keeps rising: An overview of growing income inequalities in OECD countries: Main findings. In Divided we stand. OECD. Available at http://www.oecd.org/els/soc/49499779.pdf.

Orloff, Ann Shola. 1996. Gender in the welfare state. Annual Review of Sociology, 22: $51-78$.

2006. Farewell to maternalism? State policies and mothers' employment. In The state after statism, ed. Jonah Levy, 230-68. Cambridge, MA: Harvard University Press.

. 2009. Gendering the comparative analysis of welfare states: An unfinished agenda. Sociological Theory, 27 (3): 317-43.

Portes, Alejandro, and Kelly Hoffman. 2003. Latin American class structures: Their composition and change during the neoliberal era. Latin American Research Review, 38 (1): 41-82.

Prechal, Sacha, and Susanne Burri. 2009. EU rules on gender equality: How are they transposed into national law? European Community Programme for Employment and Social Solidarity, 3-31. Available at http://ec.europa.eu/justice/gender-equality/files/ your_rights/eurulesongenderequalitytranspositionfinal2009_en.pdf.

Pribble, Jennifer. 2006. The politics of women's welfare in Chile and Uruguay. Latin American Research Review, 41 (2): 84-111. 
2013. Between elites and the masses: Political parties and welfare regimes in Latin America. Cambridge University Press.

Ray, Rebecca, Janet Gornick, and John Schmitt. 2010. Who cares? Assessing generosity and gender equality in parental leave policy designs in 21 countries. Journal of European Social Policy, 20 (3): 1-21.

Sainsbury, Diane. 1996. Gender, equality, and welfare states. New York: Cambridge University Press.

SEDLAC. 2011. Socio-Economic Database for Latin America and the Caribbean. CEDLAS and The World Bank. http://sedlac.econo.unlp.edu.ar/eng/.

UNDP/ILO. 2009. Decent work in Latin America and the Caribbean. Work and family: Towards new forms of reconciliation with social co-responsibility. Santiago, Chile: International Labour Office and United Nations Development Programme. ILO/ UNDP.

Weldon, S. Laurel. 2011. When protest makes policy: How social movements represent disadvantaged groups. Ann Arbor: MI: University of Michigan Press.

Williams, Fiona. 2010. Claiming and framing in the making of care policies: The recognition and redistribution of care gender and development programme. Paper Number 13. November. Geneva: United Nations Research Institute for Social Development. 